\title{
Age-associated changes in pancreatic exocrine secretion of the isolated perfused rat pancreas
}

\author{
Zheng-er Jiang', ChengZhe Jiang' ${ }^{2}$ Baihui Chen ${ }^{3}$, Chin Su Koh ${ }^{3}$, Jun-Hwan Yong ${ }^{4}$, \\ Dae-Hun Park ${ }^{5 *}$, Moo-Ho Won ${ }^{6}$, Yun-Lyul Lee ${ }^{3 *}$ \\ ${ }^{1}$ Teaching Center of Functional Experimental Science, College of Basic Medicine, Yanbian University, Yanji, China \\ ${ }^{2}$ Department of Veterinary Medicine, College of Agriculture, Yanbian University, Yanji, China \\ ${ }^{3}$ Department of Physiology, and Institute of Neurodegeneration and Neuroregeneration, \\ College of Medicine, Hallym University, Chuncheon, Korea \\ ${ }^{4}$ Department of Occupational Therapy, Dongnam Health College, Suwon, Korea \\ ${ }^{5}$ Department of Oriental Medicine Materials, Dongshin University, Naju, Korea \\ ${ }^{6}$ Department of Neurobiology, School of Medicine, Kangwon National University, Chuncheon, Korea
}

\begin{abstract}
Gut functions, such as gastrointestinal motility, gastric secretion and pancreatic secretion, were reduced with age. Glucose tolerance is impaired, and the release of insulin and $\beta$-cell's sensitivity on glucose are reduced with age. However, a lot of controversial data have been reported as insulin concentrations after glucose ingestion are either higher or no different in elderly and young subjects. Thus, this study was aimed to investigate whether aging could affect pancreatic exocrine secretion and its action mechanisms. An isolated perfused rat pancreatic model was used to exclude the effects of external nerves or hormones. Pancreatic secretion was increased by CCK under $5.6 \mathrm{mM}$ glucose background in the isolated perfused pancreas of young (3 months), 12 months and 18 months aged rats. There was no significant difference between young and aged rats. In 3 months old rats, CCK-stimulated pancreatic secretion was potentiated under $18 \mathrm{mM}$ glucose background. However, the potentiation effects of endogenous insulin and CCK were not observed in 12 and 18 months old rats. Exogenous insulin also potentiated CCKstimulated pancreatic secretion in 3 months old rats. Similarly, exogenous insulin failed to potentiate CCK-stimulated pancreatic secretion as that of 3 months old rats. Wet weight of pancreas and amylase content in pancreatic tissue were not changed with age. These results indicate that pancreatic exocrine secretion is reduced with age and endogenous insulin secretion and/or action is involved in this phenomenon.
\end{abstract}

Key words: Aging, glucose, insulin, cholecystokinin, exocrine secretion

Received 25 January 2013; Revised version received 27 February 2013; Accepted 1 March 2013

Aging changes functions variously in part of the body, including the gastrointestinal tract $[1,2]$. Also, aging causes obesity, diabetes and abnormality of glucose tolerance. The occurrence of these diseases, malabsorption and indigestion are very usual in old age, and these suggest that pancreatic function may be changed with age. Although the pancreas is a very important organ for digestion, effects of aging on pancreatic exocrine secretion are still unclear.

Insulin potentiates cholecystokinin (CCK)-stimulated pancreatic exocrine secretion and pancreatic polypeptide suppresses the potentiation action of insulin [3]. It has been reported that insulin receptor exists in the membrane of the pancreatic acinar cells [4-6], and insulin directly

\footnotetext{
*Corresponding authors: Yun-Lyul Lee, Department of Physiology, College of Medicine and Institute of Neurodegeneration and Neuroregeneration, Hallym University, 1 Hallymdaehakgil, Chuncheon, Gangwon 200-702, Korea

Tel: +82-33-248-2583; Fax: +82-33-255-1640; E-mail: yylee@hallym.ac.kr

Dae-Hun Park, Department of Oriental Medicine Materials, Dongshin University, 185 Gunjaero, Naju, Jeonnam 520-714, Korea Tel: +82-61-330-3263; E-mail: dhj1221@dongshin.ac.kr
}

This is an Open Access article distributed under the terms of the Creative Commons Attribution Non-Commercial License (http://creativecommons.org/licenses/ by-nc/3.0) which permits unrestricted non-commercial use, distribution, and reproduction in any medium, provided the original work is properly cited. 
enters to the acinar cells [7]. These findings suggest that insulin directly acts acinar cells and has important role to maintain exocrine secretion in the acinar cells. On the other side, it has been reported that the abnormality of glucose tolerance increases with age and the insulin secretion on maximal glucose decreases in 2 months old rats than in 12 months old rats [8]. Glucose sensitivity and responsibility of the $\beta$-cell of aged rat are low in the isolated perfused pancreas of the young rat $[9,10]$. Thus, age-related changes in pancreatic exocrine secretion may be due to insulin release or insulin action. However, it is still not clear how aging alters pancreatic exocrine secretion and islet hormones affect pancreatic exocrine secretion.

The size of the acinar cell, which takes the charge of enzyme secretion, is reduced in old men and aged experimental animals [11]. Pancreatitis occurs frequently in old men; the patient, who has geriatric chronic pancreatitis accompanied pancreatic calcification, shows the atrophy of the acinar cell and fibrosis [12]. Also, it has been reported that pancreatic juice, bicarbonate and protein secretion, which are controlled by secretin and cholecystokinin, are reduced in aged rats [13]. These results suggest that aging can reduce pancreatic exocrine secretion and islet hormones can affect the reduction of pancreatic exocrine function. The present study was performed; therefore, to investigate the effects of agerelated changes on pancreatic exocrine functions in 3, 12 and 18 months old rats.

\section{Materials and Methods}

\section{Experimental animals}

Male Sprague-Dawley rats (3, 12 and 18 months old) were used in the experiment, which succeeded in experimental animal center of Hallym University. The environment of breeding room was maintained at condition that temperature was $23 \pm 2^{\circ} \mathrm{C}$ and relative humidity was $55 \pm 10 \%$. Artificial lighting maintained 12 hours per day. The rats were anesthetized with a single intraperitoneal injection of $20 \%$ urethane (Sigma, USA) at a dose of 0.7 $\mathrm{mL} / 100 \mathrm{~g}$ of body weight. The rats were sacrificed by an intravenous overdose injection of urethane after isolation of the pancreas. Food was forbidden from rats for $24 \mathrm{~h}$ before the experiment, but they were allowed to drink water freely. This animal study was conducted in accordance with the guidelines and the approval of the Institutional Animal Care and Use Committee of Hallym
University (Hallym 2012-13).

\section{Preparation of the isolated perfused pancreas}

The isolated pancreases were prepared, according to the methods described previously $[14,15]$. In brief, the median line and the abdominal aorta was carefully dissected and cannulated with PE-50 tubing (I.D. 0.58 mm O.D. $0.97 \mathrm{~mm}$ : Clay Adams, USA) just above the celiac artery, and then tightly ligated just below the superior mesenteric artery. The pancreatic duct was also cannulated with Tygon microbore tubing (I.D. $1.27 \mathrm{~mm}$, O.D. $2.28 \mathrm{~mm}$; Fisher Scientific Co, USA) to drain the perfusate. To prevent a duodenal secretion inflow, each beginning and ending of duodenum was cannulated with plastic tubing.

The pancreas was perfused with modified KrebsHenseleit solution ( $\mathrm{pH} 7.4,305$ mosmol/kg water) through the celiac and superior mesenteric arteries at a flow rate of $1.2 \mathrm{~mL} / \mathrm{min}$, using a minipuls pump (Gilson, France). The perfusate contained $5.6 \mathrm{mM}$ glucose (Sigma, USA), $0.1 \%$ bovine serum albumin (Sigma, USA) and 3\% Dextran T-70 (Sigma, USA), and was continuously oxygenated with $95 \% \mathrm{O}_{2}$ and $5 \% \mathrm{CO}_{2}$. Krebs-Henseleit solution basically consists of $\mathrm{NaCl} 191.5 \mathrm{mM}, \mathrm{NaHCO}_{3}$ $25 \mathrm{mM}, \mathrm{KCl} 5.6 \mathrm{mM}, \mathrm{MgCl}_{2} 1 \mathrm{mM}, \mathrm{NaH}_{2} \mathrm{PO}_{4} 1.15 \mathrm{mM}$ and $\mathrm{CaCl}_{2} 2.5 \mathrm{mM}$.

The pancreas was isolated with the duodenum, but separated from neighboring organs and tissues. The pancreas was placed in temperature-controlled experimental chamber at $37^{\circ} \mathrm{C}$, which was also continuously supplied with Krebs-Henseleit solution at a flow rate of $0.35 \mathrm{~mL} /$ min and oxygenated. After equilibration period of 30 $\mathrm{min}$, pancreatic juice was collected through the experiment every 15 -min.

\section{Effects of endogenous and exogenous insulin on action of CCK}

To investigate the effects of CCK-8 under the hypoglycemic condition as a control experiment, the isolated pancreas was perfused with Krebs-Henseleit solution containing glucose at a concentration of $5.6 \mathrm{mM}$ for $45 \mathrm{~min}$, and then sulfated CCK-8 (Squibb, USA) was added to the perfusate during another $60 \mathrm{~min}$ at a concentration of $5 \mathrm{pM}$. For the purpose of observing effects of interaction of endogenous insulin and CCK, the isolated pancreas was perfused with a solution containing $18 \mathrm{mM}$ glucose instead of $5.6 \mathrm{mM}$. To see the interaction of exogenous insulin and $\mathrm{CCK}$, porcine 
insulin (Novo Nordisk) was added in the perfusate containing $5.6 \mathrm{mM}$ glucose at a concentration of $100 \mathrm{nM}$ instead of $18 \mathrm{mM}$ glucose.

\section{Measurement of amylase in pancreatic tissues}

The rat pancreas was divided from other tissues and washed with $4^{\circ} \mathrm{C}$ saline. Lymphnodes, fat tissues and vessels are removed from that pancreas. The pancreas was minced and put in polyethylene tube with phosphate buffer (20 mM, pH 8.0) $4 \mathrm{~mL}$. Then the pancreas tissues were homogenized by tissue grinder (Plytron, USA) for $30 \mathrm{sec}$ and centrifuged at a speed of $17,000 \mathrm{rpm}$ for 30 min. After centrifuge, the suspension was collected.

\section{Amylase assay in pancreatic juice}

To investigate pancreatic digestive enzyme secretion, activity of representative enzyme $\alpha$-amylase was measured. $\alpha$-Amylase activity in the pancreatic juice was determined by the method of Rick and Stegbauer (1974) [16]. In brief, $1 \mathrm{~mL}$ starch solution $(1 \%, \mathrm{w} / \mathrm{v})$ is put in $1 \mathrm{~mL}$ phosphate buffer $\left(10 \mathrm{mM} \mathrm{KH}_{2} \mathrm{PO}_{4}, 10 \mathrm{mM} \mathrm{Na}_{2} \mathrm{HPO}_{4}\right.$, $10 \mathrm{mM} \mathrm{NaCl}, \mathrm{pH}$ 6.9) and mixed with 1000-3000 times diluted pancreatic juice $(20 \mu \mathrm{L})$. Then it reacted in $37^{\circ} \mathrm{C}$ incubator for 10 minutes. One $\%$ starch solution was heated in $100^{\circ} \mathrm{C}$ for 20 minutes to melt and centrifuged in $4^{\circ} \mathrm{C}$ at a speed of $3000 \mathrm{rpm}$ for 20 minutes then the supernatant was used. After reaction, $2 \mathrm{~mL}$ dinitrosalicylic acid solution (1\% 35, 55-dinitrosalycylic acid, 30\% potassium sodium tartrate, $400 \mathrm{mM} \mathrm{NaOH}$ ) was put in it and heated in $100^{\circ} \mathrm{C}$ for 5 minutes to appear color of maltose, the reactive product. The reactive tube was cooling in room temperature for 30 minutes then measured a degree of extinction at $546 \mathrm{~nm}$ by spectrophotometer (Kontron, Swiss). Amylase activity 1 unit decided amount of amylase, which produce $1 \mu \mathrm{m}$ maltose for 1 minute with above condition and converted each 15-min (amylase output; U/15 min). Pancreatic juice was collected in polyethylene tube, which has volume of $2.4 \mu \mathrm{L} / \mathrm{cm}$ then measured length to determine the volume flow. All reagents were bought from Sigma (USA).

\section{Analysis of data}

All data were expressed as the mean $\pm \mathrm{SEM}$. The statistical significance of difference between groups was assessed with one-way ANOVA with Bonferroni's posthoc test using GraphPad Prism version 4.0 for Windows XP (GraphPad Software, San Diego, CA, USA). The difference was considered significant when the $P$ value was $<0.05$.

\section{Results}

\section{Effects of CCK-8 on pancreatic exocrine secretion}

As shown in Figure 1 and 2, when the isolated perfused rat pancreas was perfused with CCK-8, pancreatic flow rate and amylase output were increased in all the groups after $15 \mathrm{~min}$. After $45 \mathrm{~min}$, each pancreatic flow rate in 3,12 and 18 months old rats was $5.47 \pm 0.48 \mu \mathrm{L} / 15 \mathrm{~min}$, $4.37 \pm 0.79 \mu \mathrm{L} / 15 \mathrm{~min}$ and $4.94 \pm 0.76 \mu \mathrm{L} / 15 \mathrm{~min}$, respectively; all the rates were significantly elevated compared with basal secretion $(P<0.05)$. Each amylase output was also significantly elevated to $55.80 \pm 11.07 \mathrm{U} / 15 \mathrm{~min}, 39.29 \pm$ $8.17 \mathrm{U} / 15 \mathrm{~min}$ and $37.17 \pm 7.41 \mathrm{U} / 15 \mathrm{~min}(P<0.05)$. The cumulative volume flow and amylase output secreted $60 \mathrm{~min}$ of CCK perfusion had no significant difference.

\section{Effects of endogenous insulin on pancreatic secretion stimulated by CCK-8}

In order to induce endogenous insulin, the isolated rat pancreas was perfused with $18 \mathrm{mM}$ glucose after perfused with $5.6 \mathrm{mM}$ glucose background for $30 \mathrm{~min}$. Then, CCK was added after $45 \mathrm{~min}$.

As shown in Figure 3 and 4, the isolated rat pancreas was perfused with CCK under $18 \mathrm{mM}$ glucose background, and pancreatic flow rate and amylase output were significantly elevated from basal secretion, each $0.90 \pm$ $0.16 \mu \mathrm{L} / 15 \mathrm{~min}, 21.59 \pm 5.41 \mathrm{U} / 15 \mathrm{~min}$ to maximum $7.98 \pm 0.92 \mu \mathrm{L} / 15 \mathrm{~min}, 140.06 \pm 14.82 \mathrm{U} / 15 \mathrm{~min}$ after 45 min in 3 months old rats. These results were increased $153 \%$ in pancreatic flow rate and $251 \%$ in amylase output after $45 \mathrm{~min}$ under $5.6 \mathrm{mM}$ glucose. Also, total cumulative pancreatic flow rate and amylase output during 60 min were increased $36 \%$ and $111 \%$ than 5.6 $\mathrm{mM}$ glucose background. However, 12 and 18 months old rats did not represent similar results. The pancreatic flow rate in basal secretion was $1.05 \pm 0.16 \mu \mathrm{L} / 15 \mathrm{~min}$ and $1.17 \pm 0.31 \mu \mathrm{L} / 15 \mathrm{~min}$, respectively. After increased glucose level to $18 \mathrm{mM}$ and perfused with CCK for 45 min, each of them was elevated to $4.05 \pm 0.94 \mu \mathrm{L} / 15 \mathrm{~min}$ and $4.37 \pm 0.91 \mu \mathrm{L} / 15 \mathrm{~min}$; however, they were not significant compared with $5.6 \mathrm{mM}$ background. Similarly, amylase outputs were each $10.55 \pm 2.49 \mathrm{U} / 15 \mathrm{~min}$ and $12.77 \pm 3.79 \mathrm{U} / 15 \mathrm{~min}$ in basal and they were increased to $48.66 \pm 10.45 \mathrm{U} / 15 \mathrm{~min}$ and $40.12 \pm 3.11 \mathrm{U} / 15 \mathrm{~min}$ after the perfusion of CCK for $45 \mathrm{~min}$, but no significance. Likewise, cumulative total pancreatic flow rate and 

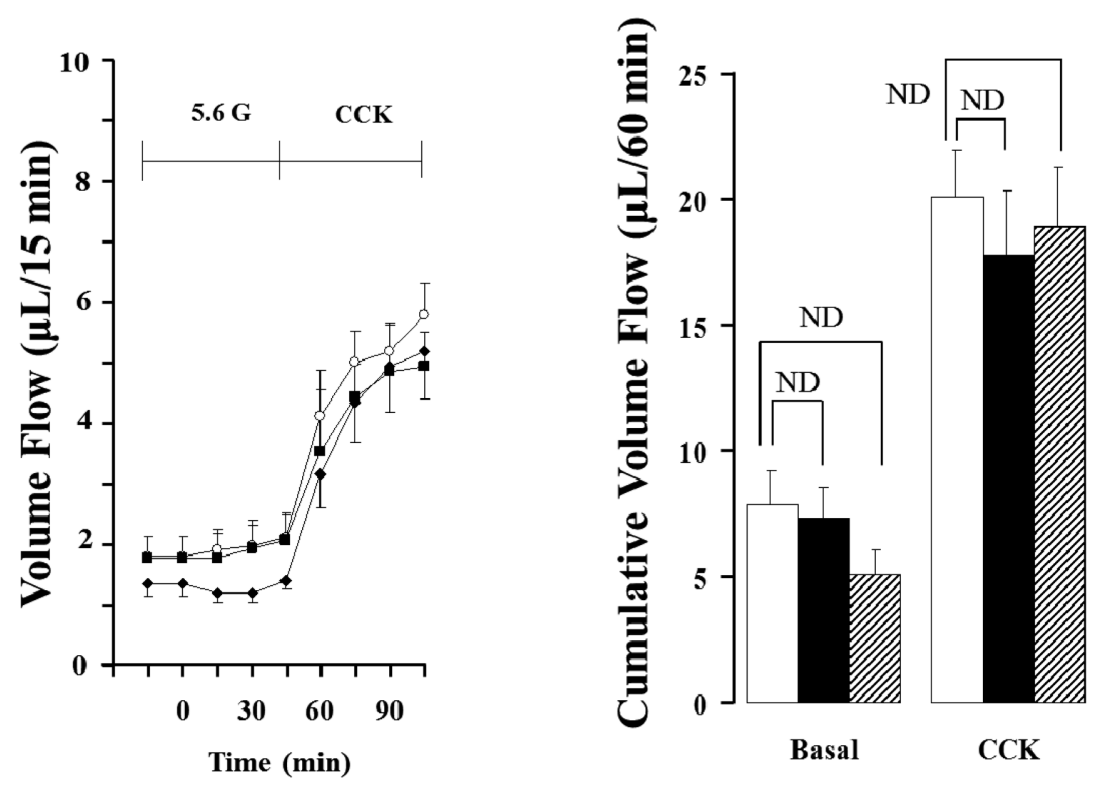

Figure 1. Effect of cholecystokinin (CCK; $5 \mathrm{pmol}$ ) in pancreatic volume flow of the isolated rat pancreas under $5.6 \mathrm{mM}$ glucose (G) background. Each point $(\bigcirc ; 3$ months old rats $(M), \mathbf{\square} ; 12$ months old rats $(M), \diamond ; 18$ months old rats $(M)$ and bar $(\square ; 3 M, \mathbf{\square} ; 12 \mathrm{M}$, $\square \rightarrow$; 18M) represent the mean $\pm S$.E of 6 experiments. Cumulative volume flow was calculated from the sum of CCK effect minus basal secretion for 60 min. ND; no significant difference.

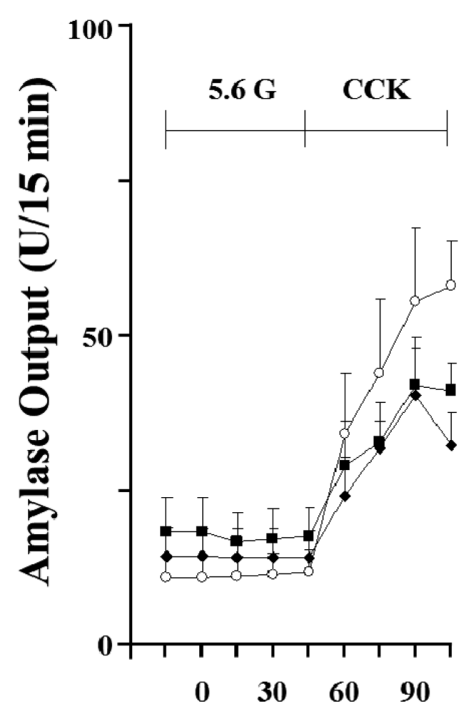

Time (min)

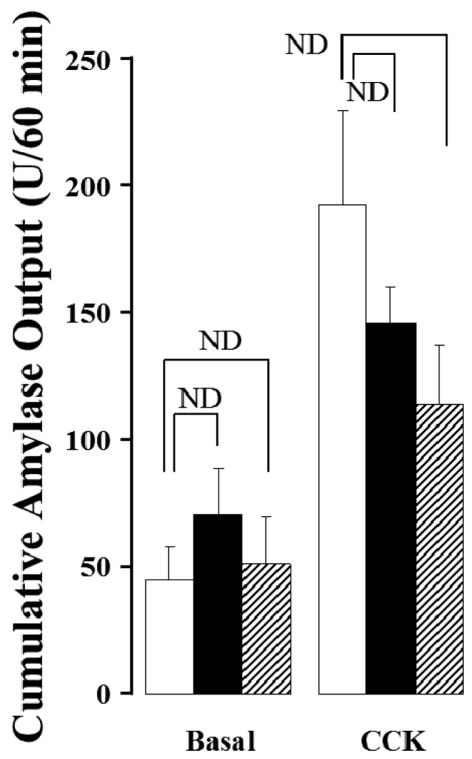

Figure 2. Effect of cholecystokinin (CCK; 5 pmol) in pancreatic amylase output of the isolated rat pancreas under $5.6 \mathrm{mM}$ glucose (G) background. Each point $(\bigcirc ; 3$ months old rats $(M), \mathbf{\square} ; 12$ months old rats $(M), \diamond ; 18$ months old rats $(M)$ and bar $(\square ; 3 M, \mathbf{\square}$ $12 \mathrm{M}, \square ; 18 \mathrm{M})$ represent the mean \pm S.E of 6 experiments. Cumulative amlylase output was calculated from the sum of CCK effect minus basal secretion for $60 \mathrm{~min}$. ND ; no significant difference.

amylase output were not affected (Figure 5).

Effects of exogenous insulin on pancreatic secretion simulated by CCK-8

Since endogenous insulin released by high concentration of glucose did not show the potentiation effect of insulin and CCK in 12 and 18 months rats as shown in Figure 3 and 4. Porcine insulin at a concentration of $100 \mathrm{nM}$ was added to the perfusate together with $\mathrm{CCK}$ after 45 min to confirm the potentiation effect of exogenous insulin. At a concentration of $100 \mathrm{nM}$ porcine insulin was added to the $5.6 \mathrm{mM}$ glucose background, and then 

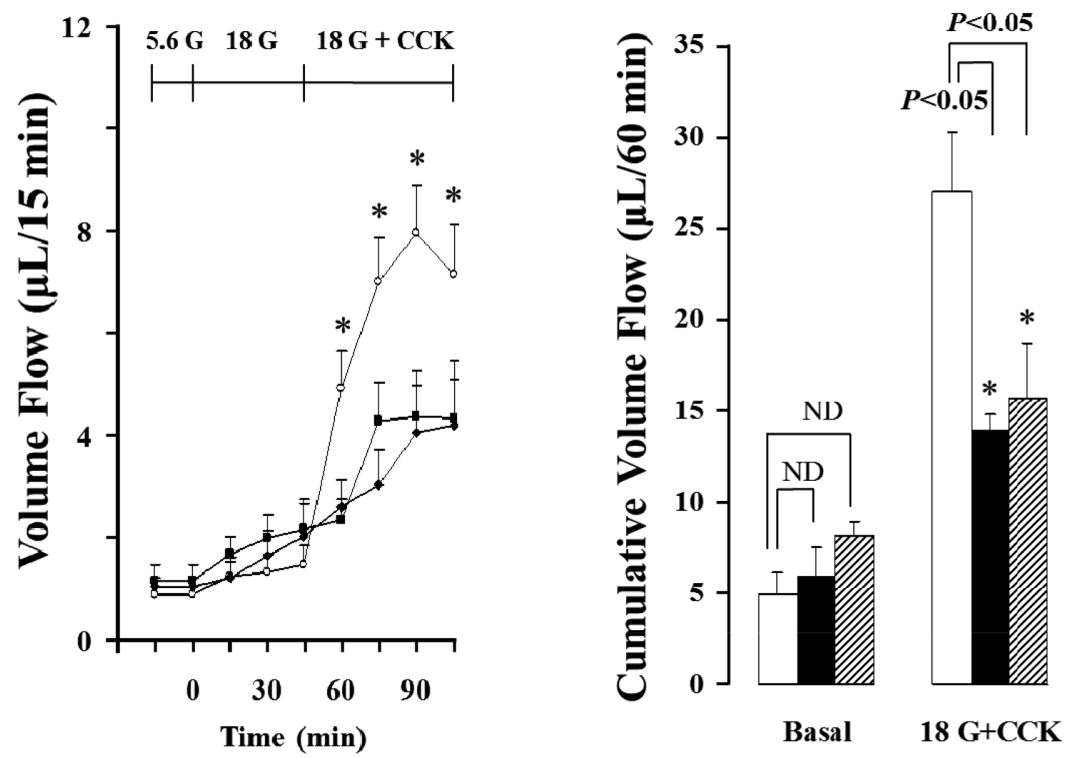

Figure 3. Effect of cholecystokinin (CCK; 5 pmol) in pancreatic volume flow of the isolated rat pancreas under $18 \mathrm{mM}$ glucose (G) background. Each point $(\bigcirc ; 3$ months old rats $(M), \mathbf{\square} ; 12$ months old rats $(M), \diamond ; 18$ months old rats $(M)$ and bar $(\square ; 3 M, \mathbf{\square} ; 12 \mathrm{M}$, $\square ; 18 \mathrm{M})$ represent the mean $\pm S$.E of 6 experiments. Cumulative volume flow was calculated from the sum of CCK effect minus basal secretion for $60 \mathrm{~min}$ *; The value is significantly $(P<0.05)$ different from that of 3 months old rats. ND; no significant difference.
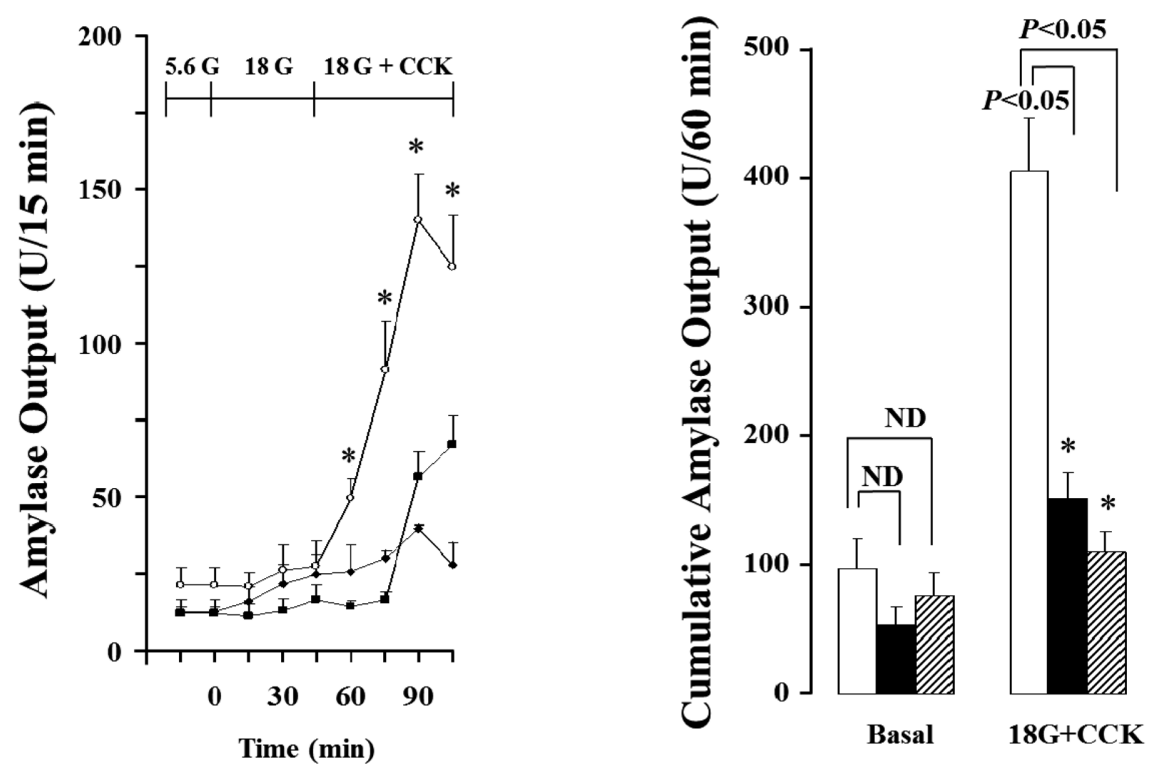

Figure 4. Effect of cholecystokinin (CCK; $5 \mathrm{pmol})$ in pancreatic amylase output of the isolated rat pancreas under $18 \mathrm{mM}$ glucose (G) background. Each point $(\bigcirc ; 3$ months old rats $(M), \mathbf{\square} ; 12$ months old rats $(M)$, $12 \mathrm{M}, \nabla ; 18 \mathrm{M})$ represent the mean $\pm S$.E of 6 experiments. Cumulative volume flow was calculated from the sum of CCK effect minus basal secretion for 60 . min. *; The value is significantly $(P<0.05)$ different from that of 3 months old rats. ND ; no significant difference.

CCK was administered to the perfusate at 45 min later.

In 3 months old rats, exogenous insulin significantly $(P<0.05)$ elevated the pancreatic flow rate and amylase output compared with that of the control $(5.6 \mathrm{mM}$ glucose background). However, exogenous insulin did not affect the pancreatic flow rate or increased amylase output; each $202.34 \pm 63.04 \mathrm{U} / 60 \mathrm{~min}$ and $162.63 \pm 30.26$ $\mathrm{U} / 60 \mathrm{~min}, 39$ and $43 \%$ increase than control data, in 12 and 18 months old rats. However, the values are not significant between the young rats and aged rats. 

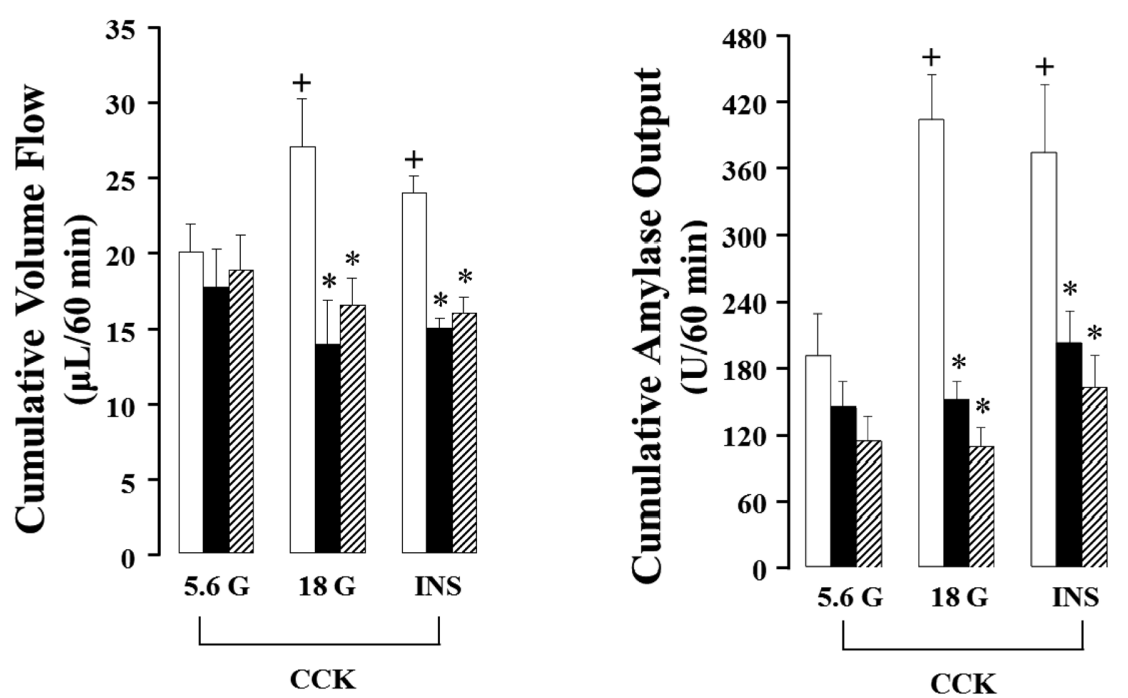

Figure 5. Effect of endogenous and exogenous insulin on cholecystokinin (CCK)-stimulated pancreatic volume flow and amylase output in the isolated rat pancreas. Each bar ( $\square ; 3$ months old rats (M), $\mathbf{\square} ; 12$ months old rats $(M), \square ; 18$ months old rats (M)) represents the mean \pm S.E. of 5 experiments. *; The value is significantly $(P<0.05)$ different from CCK-stimulated pancreatic volume flow and amylase output under $18 \mathrm{mM}$ glucose $(\mathrm{G})$ and exogenous insulin (INS) background of 3 months old rats. +; The value is significantly $(P<0.05)$ different from CCK-stimulated pancreatic volume flow and amylase output under $18 \mathrm{mM}$ glucose $(\mathrm{G})$ and exogenous insulin (INS) background in each 3 months old pancreata.

Table 1. Wet weight of pancreas in 3,12 and 18 months old rats

\begin{tabular}{cccc}
\hline Age & $\begin{array}{c}3 \text { Months } \\
(\mathrm{n}=6)\end{array}$ & $\begin{array}{c}12 \text { Months } \\
(\mathrm{n}=5)\end{array}$ & $\begin{array}{c}18 \text { Months } \\
(\mathrm{n}=5)\end{array}$ \\
\hline Wet weight $(\mathrm{g})$ & $0.812 \pm 0.05$ & $0.794 \pm 0.06$ & $0.950 \pm 0.06$ \\
\hline
\end{tabular}

There was no significant difference in the wet weigh of the pancreas.

\section{Amylase activity in pancreatic tissues}

To investigate effects of aging on amylase activity in pancreatic tissue, pancreatic amylase content was measured. Age-related changes in wet weight of pancreas were shown in Table 1. As shown in the Table, there was no significance between pancreatic wet weight of the young and old rats. Also, amylase activity in the pancreatic tissue was measured (Fig. 6). The values were $72.01 \pm$ $14.22 \mathrm{U} / \mathrm{mL}, 67.43 \pm 8.76 \mathrm{U} / \mathrm{mL}$ and $71.70 \pm 7.13 \mathrm{U} / \mathrm{mL}$ in 3, 12 and 18 months old rats, respectively. Although the amylase activity in the pancreatic tissue was recalculated as a $\mathrm{U} / \mathrm{mL} / \mathrm{g}$, the activity was also not significant among all the groups.

\section{Discussion}

In the present study, we used the isolated perfused rat pancreas to exclude the effects of the external nerves or gastrointestinal hormones. When the pancreas was perfused with $5.6 \mathrm{mM}$ glucose, the basal secretion of pancreatic flow rate and amylase output was not significant in all the groups. The pancreatic flow rate and amylase output were elevated by the administration of CCK-8 in all the groups; however, there was no significant difference between the young and aged rats. These results indicated that pancreatic exocrine secretion does not depend on age in basal or CCK-induced secretion. The other side, since the pancreas has insuloacinar axis between the endocrine part and exocrine part, islet hormones could affect exocrine secretion. Especially insulin, one of islet hormones, potentiates the action of CCK and increases pancreatic exocrine secretion $[14,17,18]$. In the 3 months old rats, we observed that the pancreatic exocrine secretion, induced by CCK, was potentiated by endogenous insulin. These data well agreed with the reports that pancreatic exocrine secretion, induced by feeding or mixture of physiological concentration of CCK and secretin, was suppressed with the administration of insulin antibody in rats [19]. In our present experiment, interestingly, the potentiation effect of insulin on the action of CCK did not appear in the 12 and 18 months old rats. When the isolated pancreas was perfused with $18 \mathrm{mM}$ glucose and CCK in the aged rats, the pancreatic exocrine secretion only increased to the similar level, which was perfused with $5.6 \mathrm{mM}$ glucose and CCK. Our results suggest that there is a possible defect of insulin release or insulin synthesize or insulin 

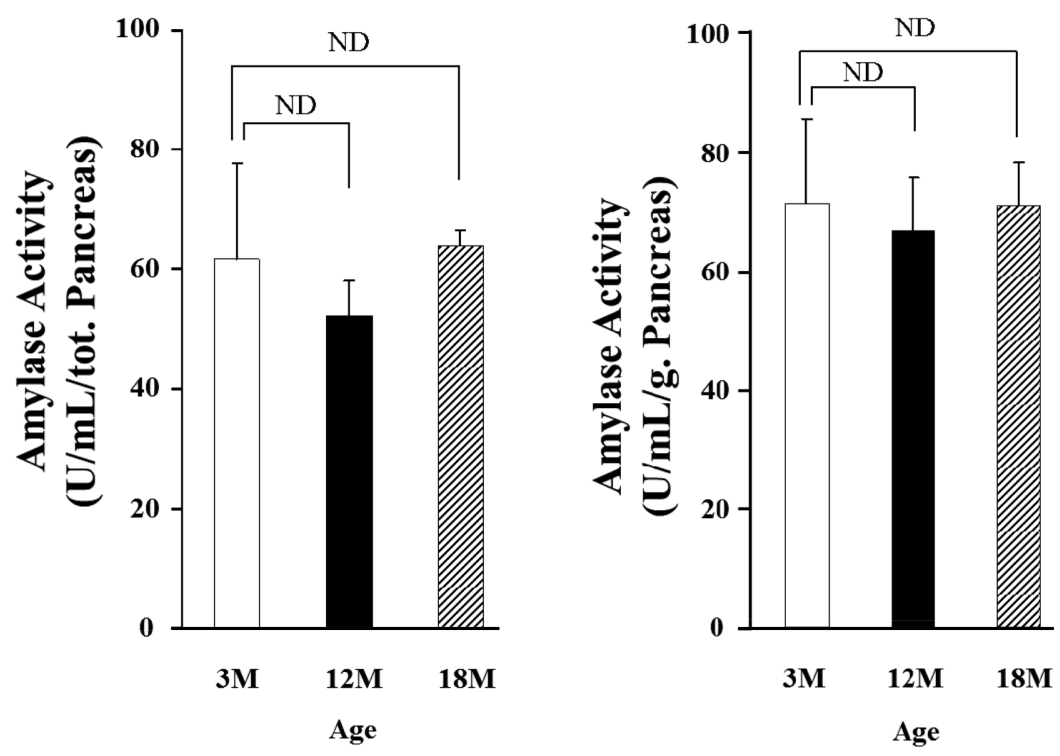

Figure 6. Amylase activity in pancreatic tissue. Each bar ( $\square$; 3 months old rats (M), rats $(M))$ represents the mean $\pm S$.E. of 5-6 experiments. ND : no significant difference.

action or other reasons with age. Therefore, to confirm whether insulin secretion induced by high concentration of glucose decreases or not with age, exogenous porcine insulin at a concentration of $100 \mathrm{nM}$ was administered with CCK in the 12 or 18 months old rats. Amylase output induced by exogenous insulin and CCK was higher than that induced by CCK alone in the 12 and 18 months old rats, each 39 and $43 \%$, respectively. However, it was significantly less than the 3 months old rats. Pancreatic flow rate was not affected in the 12 and 18 months old rats. A fact that amylase output in the aged rats was increased by exogenous insulin suggests that the insulin secretion was diminished by aging. These results are in good accord with the previous reports that there were not related with obesity, distribution of fat or physiological activity, insulin secretion, which are diminished by aging in humans $[10,20,21]$. One hand, it is not yet known what factor makes insulin secretion decrease by aging. However, it was reported that the decrease of insulin secretion resulted in the decrease of $\beta$-cell reactivity about glucose [22]. In addition, although there was high concentration of insulin in the rat pancreatic islet, $\beta$-cells, which secrets insulin, had problem on the mechanism of secretion even if it stimulated [23]. Furthermore, it was reported that insulin secretion about glucose was diminished because the adenylate cyclase activity of islet and oxidation of islet glucose were reduced by aging [24]. However, since the present study did not measure the insulin release in the perfusate eliminated through the portal vein, we could not conclude that it resulted in the decrease of insulin secretion. Therefore, further study must be carried out to measure insulin output in the perfusate.

In the present study, in spite of perfusion with exogenous insulin in the aged rats, the pancreatic flow rate did not change, and the amylase output was elevated a little, so it is supposed that other reasons besides can decrease the insulin secretion induced by the high concentration of glucose. For example, it was reported that plasma insulin concentration was not affected by aging in the fasting state [25]. In addition, it was reported that pancreatic insulin content did not differ between young and old rats; however, some researchers reported that pancreatic total insulin content was elevated by aging $[8,26]$. So, it is not clear how pancreatic insulin content changes by aging. It is clearly known that the pancreas secretes insulin and somatostatin and that somatostatin content in the islet is increased by aging and it acts an inhibitory effect on insulin secretion [27]. Therefore, it has been suggested that the content and activity of islet hormones besides insulin, which affects pancreatic exocrine secretion, can be changed with age.

It was reported that, in old humans, pancreatic anteroposterior diameter was significantly reduced, and lobulation and parenchymal fatty change became more evident [28]. As our results, 3 months old rats were significantly lower than 12 and 18 months old rats in CCK-stimulated pancreatic exocrine function, but there 
was no significant difference in the wet weigh of the pancreas. Also, pancreatic amylase content had no significance. Therefore, it was supposed that pancreatic amylase content was not affected by aging. We concluded from the present investigations that pancreatic exocrine secretion is diminished by the alteration of pancreatic function related with aging in rats and it is supposed that insulin, one of islet hormone, affects it. These phenomena may be due to a decrease in both insulin secretion and insulin action in aged rats.

\section{Acknowledgments}

This research was supported by Basic Science Research Program through the National Research Foundation of Korea (NRF) funded by the Ministry of Education, Science and Technology(2010-0008488).

\section{References}

1. Werner I, Hambraeus L. The digestive capacity of elderly people. The effect of a high protein diet. Acta Soc Med Ups 1971; 76(56): $239-242$

2. Sonnenberg A, Koch TR. Physician visits in the United States for constipation: 1958 to 1986. Dig Dis Sci 1989; 34(4): 606-611.

3. Lee YL, Kwon HY, Park HS, Lee TH, Park HJ. The role of insulin in the interaction of secretin and cholecystokinin in exocrine secretion of the isolated perfused rat pancreas. Pancreas 1996; 12(1): 58-63.

4. Bergeron JJ, Rachubinski R, Searle N, Sikstrom R, Borts D, Bastian P, Posner BI. Radioautographic visualization of in vivo insulin binding to the exocrine pancreas. Endocrinology 1980; 107(4): 1069-1080

5. Sankaran H, Iwamoto Y, Korc M, Williams JA, Goldfine ID Insulin action in pancreatic acini from streptozotocin-treated rats. II. Binding of 125I-insulin to receptors. Am J Physiol 1981; 240(1): G63-68.

6. Sjodin L, Holmberg K, Lyden A. Insulin receptors on pancreatic acinar cells in guinea pigs. Endocrinology 1984; 115(3): 11021109.

7. Goldfine ID, Kriz BM, Wong KY, Hradek G, Jones AL, Williams JA. Insulin action in pancreatic acini from streptozotocin-treated rats. III. Electron microscope autoradiography of 125I-insulin. Am J Physiol 1981; 240(1): G69-75.

8. Curry DL, Reaven G, Reaven E. Glucose-induced insulin secretion by perfused pancreas of 2- and 12-mo-old Fischer 344 rats. Am J Physiol 1984; 247(3 Pt 1): E385-388.

9. Aizawa T, Komatsu M, Sato Y, Ishihara F, Suzuki N, Nishii N, Hashizume K, Yamada T. Insulin secretion by the pancreatic beta cell of aged rats. Pancreas 1994; 9(4): 454-459.

10. Elahi D, Muller DC, Andersen DK, Tobin JD, Andres R. The effect of age and glucose concentration on insulin secretion by the isolated perfused rat pancreas. Endocrinology 1985; 116(1): 1116
11. Morgan ZR, Feldman M. The liver, biliary tract and pancreas in the aged: an anatomic and laboratory evaluation. J Am Geriatr Soc 1957; 5(1): 59-65.

12. Ammann R, Sulser H. ["Senile" chronic pancreatitis; a new nosologic entity? Studies in 38 cases. Indications of a vascular origin and relationship to the primarily painless chronic pancreatitis]. Schweiz Med Wochenschr 1976; 106(13): 429-437.

13. Khalil T, Fujimura M, Townsend CM Jr, Greeley GH Jr, Thompson JC. Effect of aging on pancreatic secretion in rats. Am J Surg 1985; 149(1): 120-125.

14. Park HJ, Lee YL, Kwon HY. Effects of pancreatic polypeptide on insulin action in exocrine secretion of isolated rat pancreas. $\mathrm{J}$ Physiol 1993; 463: 421-429.

15. Kanno T, Saito A. The potentiating influences of insulin on pancreozymin-induced hyperpolarization and amylase release in the pancreatic acinar cell. J Physiol 1976; 261(3): 505-521.

16. Jiang ZE, Shin BN, Kim IH, Lee HJ, Yong JH, Lee MJ, Won MH, Lee YL. Roles of Non-cholinergic Intrapancreatic Nerves, Serotonergic Nerves, on Pancreatic Exocrine Secretion in the Isolated Perfused Rat Pancreas. Korean J Physiol Pharmacol 2011; 15(5): 307-312.

17. Garry DJ, Garry MG, Williams JA, Mahoney WC, Sorenson RL. Effects of islet hormones on amylase secretion and localization of somatostatin binding sites. Am J Physiol 1989; 256(5 Pt 1): G897904.

18. Saito A, Williams JA, Kanno T. Potentiation of cholecystokinininduced exocrine secretion by both exogenous and endogenous insulin in isolated and perfused rat pancreata. J Clin Invest 1980; 65(4): 777-782

19. Lee KY, Zhou L, Ren XS, Chang TM, Chey WY. An important role of endogenous insulin on exocrine pancreatic secretion in rats. Am J Physiol 1990; 258(2 Pt 1): G268-274.

20. Reaven E, Curry D, Moore J, Reaven G. Effect of age and environmental factors on insulin release from the perfused pancreas of the rat. J Clin Invest 1983; 71(2): 345-350.

21. Basu R, Breda E, Oberg AL, Powell CC, Dalla Man C, Basu A, Vittone JL, Klee GG, Arora P, Jensen MD, Toffolo G, Cobelli C, Rizza RA. Mechanisms of the age-associated deterioration in glucose tolerance: contribution of alterations in insulin secretion, action, and clearance. Diabetes 2003; 52(7): 1738-1748.

22. Scheen AJ, Sturis J, Polonsky KS, Van Cauter E. Alterations in the ultradian oscillations of insulin secretion and plasma glucose in aging. Diabetologia 1996; 39(5): 564-572.

23. Borg LA, Dahl N, Swenne I. Age-dependent differences in insulin secretion and intracellular handling of insulin in isolated pancreatic islets of the rat. Diabete Metab 1995; 21(6): 408-414.

24. Lipson LG, Bush MJ, Tietjen GE, Yoon A. Role of the adenylate cyclase system in altered insulin release from islets of Langerhans of aging rats. Acta Endocrinol (Copenh) 1981; 96(2): 222-226.

25. Draznin B, Steinberg JP, Leitner JW, Sussman KE. The nature of insulin secretory defect in aging rats. Diabetes 1985; 34(11): 1168-1173.

26. Burch PT, Berner DK, Leontire A, Vogin A, Matschinsky BM, Matschinsky FM. Metabolic adaption of pancreatic islet tissue in aging rats. J Gerontol 1984; 39(1): 2-6.

27. Casad RC Jr, Adelman RC. Aging enhances inhibitory action of somatostatin in rat pancreas. Endocrinology 1992; 130(4): 24202422 .

28. Sato T, Ito K, Tamada T, Sone T, Noda Y, Higaki A, Kanki A, Tanimoto D, Higashi H. Age-related changes in normal adult pancreas: MR imaging evaluation. Eur J Radiol 2012; 81(9): 2093-2098. 